\title{
Surfaces
}

\section{The Future of Women's Studies and the Threat to Academic Feminism \\ Roundtable 1}

\section{Susan Stanford Friedman}

Volume 7, 1997

\section{LE FÉMINISME HORS DE LUI-MÊME}

FEMINISM BESIDE ITSELF

URI : https://id.erudit.org/iderudit/1064802ar

DOI : https://doi.org/10.7202/1064802ar

Aller au sommaire du numéro

Éditeur(s)

Les Presses de l’Université de Montréal

ISSN

1188-2492 (imprimé)

1200-5320 (numérique)

Découvrir la revue

Citer cet article

Friedman, S. S. (1997). The Future of Women's Studies and the Threat to

Academic Feminism: Roundtable 1. Surfaces, 7.

https://doi.org/10.7202/1064802ar d'utilisation que vous pouvez consulter en ligne. 


\title{
The Future of Women's Studies and the Threat to Academic Feminism Roundtable 1
}

\author{
Susan Stanford Friedman \\ University of Wisconsin \\ Madison
}

Surfaces Vol. VII.103 (v.1.0A - 23/06/1997) - ISSN:

1188-2492

Copyright for texts published in Surfaces remains the property of authors. However, any further publication should be accompanied by an acknowledgement of Surfaces as the place of initial publication.

Rather than attempt to synopsize my lengthy essay in Feminism Beside Itself on the epistemological and political underpinnings of feminist history writing about feminism,[ 1 ] I will adapt one section of it to the broader topic of this roundtable discussion: Feminism and the Future of Women's Studies. First, however, I will summarize a number of points I made in an oral preamble.

(1) Great thanks to Diane Elam for the vision and work she has displayed in putting together an interdisciplinary conference of academic feminists. Most often, we attend conferences related to our disciplines and participate in feminist dialogue within these boundaries. This conference opens up real possibilities of a different kind of exchange. Given the politics of the country this year, moreover, when so many of the programs that deeply affect the poorest and most vulnerable of women are under the knife, this conference also represents a great luxury. It is a luxury that we better not use selfindulgently, but rather one that offers us a metacritical space and time to look at feminism, especially academic 
feminism, within the broad perspective of our larger political responsibilities to understand and resist the dangerous and disturbing effects of the times.

(2) At this historical moment in the United States, feminism in general and academic feminism in particular are under great threat. The attacks come from a spectrum of sources-from the virulently anti-feminist, such as John Taylor's widely disseminated article in New York Magazine and the Newsweek issue on Political Correctness; to the self-identified feminist attacks by women like Christina Hoff Summers and Karen Lehrman, who have limited experience of academic feminism but condemn women's studies for its supposed non-academic nature, while claiming for themselves a pipeline to true feminism; to attacks levied by a younger generation of "postfeminists" who dislike what they dismiss as the older generation's obsession with victimology; to attacks on women's studies made by disaffected women's studies "insiders" like Daphne Patai and Noretta Koertge.[ 2 ] Most of these attacks come from outside the academy by people whose snapshots of what goes on inside the academy are highly selective and "journalistic" in the worst sense, not even remotely based on a systematic study or representational sampling of women's studies research and teaching. Whatever their own values, their attacks are greeted with glee by right wing political, religious, and financial forces. The media, sensationalizing conflict, give them great exposure-on TV and radio news and talk-shows, book tours, and the like. These attacks certainly contribute greatly to the vulnerability of women's studies in the academy, especially as the academy faces budgetary pressures and the general downsizing of higher education.

(3) We academic feminists have worked so hard to establish an oppositional discourse within the academy that we may well miss the greatest paradox of these largely external attacks-namely, that we feminists epitomize the academy to those who would attack it. I think it is imperative for our survival that we become aware of and take into account this major historical shift:

* For some twenty-five years, women's studies has defined itself in opposition to the academy, dedicating itself to the transformation of the institutions of knowledge within which it operates. Now, those attacking the academy frequently do so by using women's studies as the epitome of what's wrong with higher education. In the public arena, women's studies has become entirely identified with the institution that we have seen ourselves committed to transforming. 
* For some fifteen to twenty years, women's studies has worked through issues of the differences among women based on factors such as race, class, sexuality, religion, national origin, and so forth. Now, those attacking women's studies completely identify it with multiculturalism, postcolonial studies, and gay and lesbian studies, largely for the purpose of condemning all these presences in higher education. The differences and divisions that have greatly preoccupied us-with such good and important effects for feminist theory and practice-are mainly invisible in the larger public arena, where people dismiss the changes wrought by women's studies, ethnic studies, postcolonial studies, cultural studies, and gay and lesbian studies as a single plot against the glories of Western culture and civilization.

* For some fifteen years, academic feminism, especially in the humanities but increasingly in many of the qualitative social sciences as well, has been fraught with conflict over the issue of poststructuralist theory-the various currents of philosophical thought tied to the work of French intellectuals like Lacan, Derrida, Foucault, Kristeva, Althusser, Cixous, Irigaray, and the like, all of which in some way mount an attack on humanism and insist upon the problematization of the ground upon which we stand. Now, those attacking women's studies often do so by identifying it with "theory," especially deconstruction, refusing to see the complicated, conflictual, and often highly productive relationship between poststructuralism and feminism and condemning both as engaged in the destruction of Western culture.

I conclude from this historical shift that it is imperative that we academic feminists look beyond the divisions within women's studies and within the academy to the larger societal context. Why are all those dedicated to the critique of the academy used to epitomize the academy? Why are all of us who are at odds with each other lumped together as the same? What do these things mean for our survival? In what way can and must we ally with the institution of the academy itself, which is so under attack in the larger society?

(4) Much of the attack on women's studies challenges academic feminism with the whole right wing discourse of Political Correctness. The term "PC," developed and used by the left as a largely self-mocking and ironic critique of the tendency to orthodoxy or "correct line" thinking, has been appropriated by the right wing to characterize and condemn all our activity, as Ruth Perry 
so ably shows in her essay on the history of the term.[ $\underline{\mathbf{3}}$ ] In the face of this appropriation, we have a difficult task. Any time that academic feminists publically critique women's studies for fundamentalist orthodoxy or excesses of any kind, we face the very real possibility of our critique of one strain in women's studies being used by others to discredit the whole project of women's studies. This danger is a very real one, evident in the kind of cultural work Daphne Patai and Noretta Koertge's Professing Feminism has done, which I suspect goes well beyond their stated intentions of getting academic feminists to speak up about their dissatisfactions with women's studies. Nonetheless, I think it is imperative for the survival and growth of women's studies that we continue public critique of ourselves. At the same time, we must be aware of how our debates can be used by those who would eliminate us altogether from the arena of debate.

(5) There are of course many strategies for dealing with the threats to academic feminism. As others have argued, we certainly need to have more spokeswomen and men who can effectively communicate to the general public what is involved in feminist research and pedagogy. We need to teach our students, especially our women's studies majors, how better to explain the parameters of feminist education once they leave the academy. But I do not believe that this difficulty in communicating to a general public is solely the problem of academic feminism. Rather, we exhibit the same communicative difficulties the rest of the academy has in explaining our activities. The academy in generalwomen's studies along with it-has failed to educate the public about the nature of our research and pedagogical missions. As a faculty member from a large, land-grant institution whose fate is annually debated in the state legislature in lurid terms, I am acutely aware of how much we have to do to clarify the general mission of higher education in the future of society. I am aware as well of how poorly we have done so.

(6) Another strategy for dealing with the external and internal threats to women's studies requires selfreflexive and self-critical interrogation of the epistemology bases of academic feminism: objectivism (or positivism) and subjectivism (or constructionism). If we better understand the underlying, often taken-forgranted assumptions that underlie our field, then we have a better chance of developing ways of communicating with the general public at large. I see this interrogation for our own consumption as $a$ (not the) necessary task in developing ways of defending women's 
studies against attack, from whatever quarter. This, I take it, was one of the larger objects of Diane Elam and Robyn Wiegman's Feminism Beside Itself. I will turn now to a section of the essay that I wrote for their collection on what I see as the epistemological contradiction that drives women's studies now and has been present since the very beginning, a contradiction that is related to our roots in feminist activism, the need not only to know, but to do. I quote from the article:

Both objectivist and subjectivist epistemologies have been at work in women's studies as feminists from a variety of fields engage in "making history"-in the writing about feminism's past and the performance of feminism's present and future. Some feminists work within a positivist framework, emphasizing the "truth" of what has been recovered; others function within a subjectivist framework, foregrounding the interpretive dimension of their narratives; and still others combine aspects of each epistemology. This diversity of historiographic assumption reflects, I believe, the contradictions built into the foundations of women's studies itself, contradictions that continue to underlie and permeate most work in the field, whether acknowledged or not. On the one hand, women's studies developed out of the need to counter hegemonic discourses about women that ignored, distorted, or trivialized women's history, experience, and potential. Women's studies consequently formulated compensatory and oppositional histories that told the "truth" about women-whether it was about women's status in the so-called Renaissance, the production of women's writing in the nineteenth century, or the sexual brutalization of black women slaves. This search to discover of the "truth" of women's history that could shatter the "myths" and "lies" about women in the standard histories operates out of a positivist epistemology that assumes that the truth of history is objectively knowable.

On the other hand, the early insistence in women's studies that hegemonic knowledge was produced out of and in the service of androcentrism necessitated a subjectivist epistemology that insisted on all knowledge as value-based, emerging from a given perspective or standpoint. No knowledge is 
value-free, many feminists claimed, including feminist knowledge. Thomas Kuhn's The Structure of Scientific Revolutions(1962) was widely used to promote women's studies as a "paradigm shift" of dramatic and revolutionary proportions within the institutions of knowledge.[ $\underline{\mathbf{4}}$ ]

The goal of writing history within this epistemological framework was not to discover the true history, but rather to construct the story of women's experience out of a feminist paradigm. Feminist histories countered hegemonic histories not with the objective truth, but with stories produced from a feminist perspective.

Both feminist epistemologies developed out of and have continued currency because of the urgently felt political agenda of women's studies: to engage in the deformation of phallocentric history and the reformation of histories that focus on or integrate women's experience and the issue of gender. Why political? Because what we know of the past shapes what becomes possible in the future. Because the repositories of human knowledge constitute the building blocks of the symbolic order. Because knowledge is power, ever more increasingly so in what is coming to be called the Information Age. As much as my own work and sympathies operate primarily out of the subjectivist epistemology, I believe that both are necessary to the enterprise as moderating influences on the potential excesses of each. On the one hand, the positivist epistemology can lead toward fundamentalist assertions of truth that obscure the interpretive perspectives of historical narrative. On the other hand, the subjectivist epistemology can lead toward the paralysis of complete relativism in which the Real of history vanishes into the play of story and discourse. The epistemologies underlying feminism should aim for a negotiation between objectivism and subjectivism, between the search for the Real and a recognition that all access to the Real is mediated through discourse (14-15). 


\section{NOTES}

1. Susan Stanford Friedman, "Making History: Reflections on Feminism, Narrative, and Desire," Feminism Beside Itself, eds. Diane Elam and Robyn Wiegman (London: Routledge, 1995), pp. 11-54.

2. See for example John Taylor, "Are You Politically Correct?" New York Magazine (January 21, 1991) pp. 32-41; Christina Hoff Sommers, "Sister Soldiers," The New Republic (October 5, 1992) pp. 29-33; Sommers, Who Stole Feminism? (New York: Simon and Schuster, 1994); Karen Lehrman, "Off-Course" Mother Jones Magazine (September/October 1993) pp. 45-51, 64-66; Daphne Patai and Noretta Koertge. Professing Feminism (New York: Basic Books, 1995). See also the special issue on Sommers of Democratic Culture 3 (Fall 1994).

3. Ruth Perry, "A Short History of the Term Politically Correct," Beyond P.C.: Toward a Politics of Understanding, ed. Patricia Aufderheide (St. Paul, MN: Greywolf Press, 1992), pp. 71-79.

4. See for example Sandra Coyner's "Women's Studies as an Academic Discipline," in Theories of Women's Studies, eds. Gloria Bowles and Renata Duelli Klein (London: Routledge and Kegan Paul, 1983), pp. 46-71.

Accueil Surfaces | Table des matières | Recherche Surfaces Home Page | Table of Contents | Search

PUM | Livres | Revues | Publications électroniques | Vente et distribution 